\title{
Sexo, Simulacro e POLÍ́ticas da PaRódia
}

Vladimir Safatle

\section{Resumo}

Trata-se de discutir a noção deleuzeana do humor enquanto modo de dizer a verdade do que é da ordem do sexual e enquanto forma de crítica à submissão do desejo à Lei. O humor deleuzeano, conforme é apresentado em textos como Logique du sens e, principalmente, Présentation de Sacher-Masoch, aproxima-se de considerações lacanianas sobre o semblante e a estrutura do fetiche. Tal aproximação visa mostrar as limitações de uma crítica como a pensada por Deleuze. Por fim, a noção de paródia, tal como é tratada por Judith Butler, é apresentada como um desdobramento possível da perspectiva deleuzeana.

Palavras-chave: Humor. Ironia. Paródia. Fetiche. Semblante.

\section{SEX, SIMUlacRUM AND POLITICS OF PARODY}

\begin{abstract}
This article aims to discuss the deleuzean idea of humor as way to say the truth about sex and as way to criticize the desire's submission to Law. We can find something similar as deleuzean humor (how it is developed in Logique du sens and Présentation de Sacher-Masoch) in lacanian's considerations about the structures of semblance and fetishism. This similarity can show us the limitations of that deleuzean use of humor to criticize the desire's submission to Law. At the end, the Judith Butler's notion of parody is presented as a sort of continuation of deleuzean standpoint.
\end{abstract}

Keywords: Humor. Irony. Parody. Fetish. Semblance.

* Professor do Departamento de Filosofia da Universidade de São Paulo.

Endereço: Rua Dr. Homem de Melo, 629, apto. 2021, CEP 05007-001.

E-mail:vsafatle@yahoo.com. 
Uma rebelião simbólica em uma cidade simbólica, apenas as torturas eram verdadeiras

Sartre, Paris sous l'Occupation

\section{SeXo E RECONCILIAÇÃo}

Em 3 de março de 1794, Saint-Just afirmava na tribuna da Convenção, pensando nas possibilidades abertas pela Revolução francesa: "A felicidade é uma idéia nova na Europa". A declaração indicava uma consciência clara da transformação da felicidade em fator central da ação social. Estávamos longe da compreensão da felicidade como simples "cuidado de si" resultante de práticas e experiências que não tomam por referência uma Lei geral reconhecida universalmente. Para Saint-Just, a felicidade era uma idéia nova na Europa porque, pela primeira vez, ela poderia guiar a racionalidade das esferas que compõem o político. Neste sentido, o primeiro parágrafo da Declaração que precede a Constituição de 1793 não poderia ser mais claro: "O objetivo da sociedade é a felicidade geral (bonheur commune) e o governo é seu defensor".

Que a promessa de realização de uma política da felicidade apareça em um momento histórico fundador da modernidade política, isto é algo que não nos surpreende. A escatologia própria a toda política revolucionária moderna depende da promessa utópica da efetivação possível de uma realidade jurídica na qual Lei social e satisfação subjetiva possam enfim aparecer reconciliadas.

É por levar em conta as aspirações do princípio de subjetividade no interior da esfera do político que podemos dizer que estamos diante de uma noção de felicidade enquanto fenômeno eminentemente moderno. Notemos a tensão interna à felicidade na sua versão moderna. Ela deve englobar, ao mesmo tempo, imperativos de reconhecimento da singularidade dos sujeitos e imperativos de integração da multiplicidade dos sujeitos na unidade do corpo social e de suas representações. Devemos, assim, falar em tensão interna à felicidade porque ela deve dar conta de dois imperativos aparentemente antagônicos. Há, na aurora do projeto moderno, uma articulação fundamental entre felicidade e universalidade que nos explica, entre outras coisas, por que todos os grandes projetos de teoria política na modernidade estão de acordo em pelo menos um ponto: a ação política que visa à felicidade subjetiva deve produzir a reconciliação objetiva com o ordenamento jurídico de uma figura institucionalizada do Universal (de preferência, com a realidade jurídica do Estado justo).

Sabemos que uma das estratégias maiores de uma certa tradição crítica do pensamento do século XX consistiu em insistir no fato de que a possibilidade desta reconciliação dependeu de uma preparação do campo das singularidades dos sujeitos. Preparação que tocava profundamente aquilo que é da ordem do sexual. Lembremos da tese foucaultiana, hoje amplamente conhecida: a contrapartida à hipótese da realização objetiva da felicidade no interior da realidade jurídica do Estado justo foi posta à custa de uma metamorfose maior naquilo que diz respeito ao sexo. Não se trata de dizer que este ideal de felicidade fora fundado sobre a simples repressão da realidade sexual. Ao contrário: "o que é próprio das socieda- 
des modernas não é o terem condenado o sexo a permanecer na obscuridade, mas sim o terem-se devotado a falar dele sempre, valorizando-o como $o$ segredo" (FOUCAULT, 1986, p. 36). Pois, se há alguma forma de repressão, ela é exatamente o contrário do ato de silenciar o que é da ordem do sexo. Ela encontra-se nos processos de normatização do sexo na ordem social por meio de uma biopolítica assentada na proliferação de discursos médicos, jurídicos e morais sobre a conduta sexual. Como se o dizer da verdade do sexo naturalmente se conciliasse com alguma forma universal da Lei.

Aqui, valeria a pena introduzirmos algumas considerações vindas da experiência psicanalítica, já que ela marca um momento central na inflexão crítica do pensamento do século XX, no qual parecem convergir duas disposições contrárias: a insistência na impossibilidade de realização de tais promessas de reconciliação e a tentativa de conservá-las por meio de uma rearticulação do problema da universalidade.

"Coisa curiosa", diz Lacan (1986, p. 71), "a felicidade em quase todas as línguas apresenta-se em termos de reencontro - $\tau v \chi \eta$ ”. Nós sabemos qual a natureza deste reencontro. Ela diz respeito à adequação entre as aspirações do princípio de subjetividade e os imperativos sociais. Lacan é tão cônscio disto que, após afirmar que "a felicidade transformou-se em um fator da política", ele complementa: "não poderia haver satisfação de um fora da satisfação de todos". De onde se segue uma certa permanência da função do Universal e das exigências de realização de demandas de reconciliação.

No seminário sobre $O$ avesso da psicanálise, ao comentar a frase de SaintJust a respeito da felicidade como idéia nova na Europa, Lacan completa com a assertividade de quem está falando algo óbvio: "só há felicidade do falo" (LACAN, 1966, p. 82). Uma simples boutade surrealista ao gosto do autor? Não exatamente. Em Lacan, os processos de socialização são fundamentalmente processos de sexuação, ou seja, modalidades de subjetivação do campo do sexual. Neste sentido, a interação social por meio da submissão à universalidade da Lei simbólica visa, principalmente, inscrever os sujeitos e seus corpos em modos reconhecidos de sexuação. Para Lacan, todos esses modos organizam-se a partir de um significante central: o falo. Daí afirmações como: "o falo é o significante fundamental por meio do qual o desejo do sujeito pode se fazer reconhecer enquanto tal, quer se trate do homem ou quer se trate da mulher" (LACAN, 1998, p. 273). Ou seja, a socialização do desejo de todo e qualquer sujeito passaria necessariamente pela articulação com o Falo, ou pelo seu excesso.

Assim, se é verdade que a felicidade, tal como a modernidade a concebeu, só é possível lá onde há adequação entre o sexual e o Universal da Lei, então só poderia haver felicidade do falo. No que a crítica de pós-estruturalistas como Derrida e Deleuze seria certeira: falocentrismo com conseqüências políticas inibidoras devido à hipóstase de uma Lei simbólica de forte conteúdo normativo e regulador que esqueceria aquilo que o sujeito deve perder a fim de passar por processos de sexuação. Uma hipóstase historicamente desproporcional, já que nossa época se- 
ria marcada exatamente pelo declínio da "imago" paterna e da centralidade do modo fálico de sexuação.

Mas vale a pena insistir em uma certa "ironia" constitutiva da estratégia lacaniana de reconciliação. Enquanto "significante fundamental", o falo é, segundo Lacan, um significante puro, sem força denotativa; ele não denota objeto algum. Lembremos da famosa definição de Lacan: "O significante é um sinal que não remete a um objeto" (LACAN, 1981, p. 119). Neste sentido, o significante puro pode ser compreendido como a formalização da impossibilidade de a linguagem adequar-se aos objetos empíricos. O que nos mostra como a submissão da diversidade dos modos de sexuação a um significante puro traz, como consequiência, a anulação de todo objeto empírico (como, por exemplo, o pênis orgânico e todo objeto empírico que venha a tentar substituí-lo, como, por exemplo, o fetiche) enquanto objeto de desejo e função de gozo. A Lei do falo, segundo Lacan, seria "vazia", pura forma desprovida de qualquer conteúdo substantivo e que indicaria, apenas, que o desejo do sujeito não pode se esgotar em vínculos privilegiados com objetos empíricos.

Isso talvez possa nos explicar o movimento duplo de Lacan ao caracterizar o falo. Raramente prestamos a devida atenção no fato de que, em Lacan, o falo é, ao mesmo tempo, presença real do desejo e significante que encarna a falta própria à castração. Nós estamos diante de uma contradição aparente, salvo se admitirmos a existência de algo como um "desejo de castração". Entretanto, se lembrarmos que a castração lacaniana não indica, como em Freud, a ameaça fantasmática que pesa sobre o pênis devido à relação de rivalidade com o pai ligada à posse do objeto materno, mas a impossibilidade estrutural de todo e qualquer objeto empírico (o pênis, por exemplo) ser função de gozo, então a estratégia fica clara. Pois o falo é a maneira disponível ao sujeito para que este determine objetivamente a negatividade radical de seu desejo. Se Lacan afirmou que o falo é presença real do desejo, "significante do gozo" (LACAN, 1966, p. 823), era apenas para completar que se trata de uma "presença do negativo": "um símbolo geral desta margem que sempre me separa de meu desejo" (LACAN, 1998, p. 243).

A ironia fica por conta da afirmação de que os sujeitos só podem socializar seus desejos por meio do vínculo a um significante que apenas formaliza a inadequação de todo conteúdo empírico ao desejo. Como se a verdade do sexo devesse necessariamente ser dita de maneira irônica (e não seria por outra razão que o próprio Lacan nunca cansava de falar da "comédia" do falo e não é por outra razão que ele se interessa tanto pelo Witz como modo de simbolização do desejo). ${ }^{1}$

Neste sentido, lembremos como, desde há muito, a ironia foi compreendida como posição subjetiva marcada por aquilo que Kierkegaard (1991) um dia definiu como sendo "negatividade infinita absoluta", ou seja, uma estilização da negatividade do sujeito em relação a toda determinação empírica, a todo papel identitário que determina um fazer social. Pois, ao expor continuamente a distância entre sujeito do enunciado e sujeito da enunciação, o ironista aparece como aquele que nunca está presente na determinidade do seu dizer, aquele que nunca fornece uma ima- 
gem adequada de si. Mas essa perspectiva singular de reconciliação entre a verdade do sexual e a universalidade da Lei do falo não deixará de apresentar problemas à Lacan.

\section{TRANSCENDÊNCIA E SUPERFÍCIE}

Mas, por hora, mudemos de perspectiva, pois, no interior desta discussão sobre os modos de enunciação do sexo como lugar de verdade, Deleuze representa, à sua maneira, uma inflexão peculiar e bastante distinta dessa estratégia lacaniana. Podemos dizer que a articulação entre sexo e campo da verdade continua absolutamente válida para Deleuze, com a condição de levarmos em conta uma certa modificação maior na lexis do falar franco sobre o sexo. De uma certa forma, para Deleuze, a palavra que revela a verdade sobre o campo do sexual deve estar necessariamente marcada pela "paródia" e pelo "humor", e não pela ironia. Ela não promete a reconciliação com o universal da Lei (mesmo com uma Lei que é pura forma, como em Lacan), nem a insistência no particularismo do desejo sexual, mas a "desarticulação" do campo do universal por meio do humor.

Para compreendermos esse ponto devemos lembrar que Deleuze enquadra a relação ao sexual no interior de uma teoria do humor. Por sua vez, essa teoria do humor irá fornecer o regime de imanência em relação à positividade do desejo.

Deleuze parte de uma distinção estrita entre ironia, humor e sarcasmo que será construída principalmente em dois livros: Lógica do sentido e Apresentação de Sacher-Masoch. Todos os dois nos servirão de guia aqui. Deleuze afirma que conhecemos, principalmente, dois modos de subverter a Lei. Um é a ironia enquanto operação que procura regionalizar a Lei ao insistir na posição de uma Lei ainda mais elevada e incondicional. Ou seja, seguindo a tradição romântica que vê na ironia uma "bufonaria transcendental", Deleuze compreende a ironia como um modo privilegiado de recurso à transcendentalidade da Idéia. De onde se segue a definição: "sempre chamamos de ironia o movimento que consiste em ultrapassar a lei em direção a um princípio mais alto, isto a fim de reconhecer à lei apenas um poder segundo" (DELEUZE, 1967, p. 75).

À sua maneira, Deleuze compõe um grande e heteróclito quadro de relações de família que começa na ironia socrático-platônica com suas estratégias de autenticação da Idéia. Ironia que Deleuze lembra ao dizer: "Platão ria destes que se contentavam em fornecer exemplos, de mostrar, de designar, ao invés de apreender as essências: Eu não te pergunto (dizia ele) o que é justo, mas o que é o justo etc" (DELEUZE, 1969, p. 160). Para Deleuze, algo desse riso que zomba das expectativas de determinações empíricas em fundamentar o advento do sentido poderá ser ouvido em um autor que nada teria de platônico: Sade. O mesmo Sade, cuja ironia consiste em regionalizar as aspirações universalizantes da Lei moral a fim de insistir na imanência de uma Lei mais alta, fundada na natureza, com suas injunções de gozo: "Partindo da idéia de que a lei não pode ser fundada pelo Bem, mas deve repousar em sua forma, o herói sádico inventa uma nova maneira de ascender da lei a um princípio superior; mas tal princípio é o elemento informal de uma natureza primeira destrutora de leis" (DELEUZE, 1967, p. 79). 
Ou seja, da ironia socrática à ironia moderna (Sade), passa-se da regionalização da Lei pela substancialidade do Bem supremo à regionalização da Lei por um princípio que é apenas a posição da "pura forma", mesmo que essa pura forma ganhe a figura de uma natureza primeira caracterizada pelo impulso de destruição de todo e qualquer conteúdo sensível. Por trás dessas aproximações inusitadas, Deleuze procura insistir nos impasses de uma estratégia de constituição da experiência do sentido a partir de motivos da transcendência. Por outro lado, ele enxerga em Sade a realização mais bem acabada de uma estratégia que insiste na inadequação radical do desejo aos objetos empíricos: o resultado só poderá ser o impulso de destruição serial de tudo o que se colocar como objeto do desejo para que o vazio da pura forma possa ser posto. ${ }^{2}$

O outro modo de subverter a Lei é o humor. "Nós chamaremos humor, não mais o movimento que ascende da lei a um princípio mais alto, mas este que desce da lei em direção às consequiências" (DELEUZE, 1967, p. 77). Ou seja, não se trata de regionalizar o ordenamento produzido pela Lei por meio da posição de um princípio que a transcende, mas se trata de "torcer" a lei pelo aprofundamento de suas conseqüências. Seguiremos a Lei ao pé da letra, respeitaremos os critérios normativos que aspiram fundamentar a orientação no julgamento, mas faremos de maneira tal que eles justifiquem consequiências que pareciam inicialmente contraditórias em relação à Lei. O humor é, assim, esta capacidade de fazer a Lei justificar disposições performativas que lhes pareceriam contraditórias. Se Deleuze pode afirmar que o humor é a co-extensividade entre o sentido e o não-sentido, é porque ele quer demonstrar que a significação da Lei pode ser consistente com uma pragmática que normalmente lhe seria estranha.

Não deixa de ser ilustrativo que, este humor, Deleuze o encontre inicialmente na crítica ao platonismo operada pelos cínicos, pelos estóicos e pelos megáricos:

O humor é esta arte de superfície contra a velha ironia, arte de profundezas e alturas. Os Sofistas e os Cínicos já haviam transformado o humor em uma arma filosófica contra a ironia socrática, mas com os Estóicos o humor encontra sua dialética, seu princípio dialético e seu lugar natural, seu conceito filosófico puro (DELEUZE, 1969, p. 18).

Este humor, os estóicos e cínicos teriam encontrado por meio do uso do simulacro. O que nos interessa aqui é - para além da adequação ou não desta leitura da história da filosofia que coloca, lado a lado, sofistas e cínicos - a maneira deleuzeana de, por meio de uma certa reatualização da crítica ao platonismo, insistir na necessidade de reabilitar o simulacro e sua desarticulação das noções de cópia e de modelo, isto a fim de fornecer um dispositivo de crítica ao pensamento da representação. O simulacro coloca-se como se fosse o que se modela a partir da Idéia. No entanto, este "como se" é uma estratégia para mostrar que a Idéia não tem a força de assegurar um campo fundamentado de aplicação. Pois o simulacro é aquilo que se coloca como realização da Idéia, mas tem deliberadamente apenas um "efeito de semelhança exterior e improdutivo obtido por astúcia e subversão" (DELEUZE, 1969, p. 298). Daí porque Deleuze poderá afirmar que "A 
cópia é uma imagem dotada de semelhança”, e que, "o simulacro é uma imagem sem semelhança" (DELEUZE, 1969, p. 297). Dessa forma, o simulacro desautoriza a partilha entre verdadeiro e falso a partir da aplicação da Idéia e bloqueia a lógica da representação como subsunção da imagem à determinação do objeto. Ele será "a mais alta potência do falso" (DELEUZE, 1969, p. 303), dirá Deleuze, parafraseando Nietzsche. Uma certa realização da Idéia que inverte suas expectativas performativas.

\section{O humor de Sacher-Masoch, Segundo Deleuze}

Mas voltemos às reflexões sobre o humor e o dizer do sexo. Assim como Deleuze vê, em Sade, um exemplo privilegiado da transcendentalidade da ironia em ação no campo da organização da sexualidade, ele verá em Sacher-Masoch o exemplo de uma sexuação pensada a partir da teoria do humor. Há um largo movimento em Deleuze que consiste em recorrer ao masoquismo e à perversão a fim de tentar transformá-los em exemplos deste humor capaz de instaurar uma relação de imanência com um plano de simulacros. É por meio desses exemplos que Deleuze procura mostrar como o dizer da verdade do sexo deve necessariamente obedecer à dinâmica do humor.

Vimos como Deleuze instaurava uma dicotomia entre ironia e humor a fim de dizer que, se a ironia consiste em ultrapassar a Lei "pelo alto", o humor visaria "torcer" a Lei mediante aprofundamento de suas consequiências. Não colocamos nenhum princípio de significação para além da Lei moral. Esta é seguida por meio de uma aplicação escrupulosa: "Toma-se a lei ao pé da letra, não se contesta seu caráter último ou primeiro" (DELEUZE, 1967, p. 77). Mas os efeitos da Lei são invertidos devido à possibilidade de "designações" múltiplas que demonstram como a tentativa de fundar o sentido mediante designações nos leva necessariamente a um impasse. Assim, vimos que, se Deleuze pode afirmar que o humor é a coextensividade entre o sentido e o não-sentido, é porque ele quer demonstrar que a significação da Lei é consistente com uma pragmática que normalmente lhe seria estranha: "a mais estrita aplicação da lei tem o efeito oposto a este que normalmente esperávamos (por exemplo, os golpes de chicote, longe de punir ou prevenir uma ereção, a provocam, a asseguram)" (DELEUZE, 1967, p. 78).

Já vimos que o exemplo maior vem de Sacher-Masoch, este mesmo SacherMasoch em quem Deleuze vê uma insolência por obsequiosidade, uma revolta por submissão. Mas perderemos toda a especificidade da relação do masoquista à Lei se virmos aqui apenas um caso de "hipocrisia", ou seja, de ação "conforme" a Lei que esconde, sob a conformação à universalidade do princípio, interesses particulares de gozo. $\mathrm{O}$ verdadeiro desafio do masoquismo consiste em mostrar que a transcendentalidade da Lei pode sustentar conseqüências que lhe são normalmente contrárias, "sem que isto implique necessariamente contradição performativa".

Por exemplo, seguir a Lei é inicialmente regular sua conduta a partir de um imperativo categórico, universal e incondicional capaz de pôr um princípio de racionalidade na dimensão prática e afastar o determinismo próprio à causalidade natural. Isso nos revela tanto a existência de uma vontade livre e purificada de 
todo vínculo privilegiado com os objetos empíricos quanto um horizonte regulador da conduta. Horizonte capaz de fundar um espaço transcendental de reconhecimento intersubjetivo da autonomia e da dignidade dos sujeitos, espaço no qual eles nunca serão tratados como simples meios ou instrumentos do gozo do outro.

Nesse sentido, uma das inversões maiores do masoquismo consiste em mostrar que uma vontade livre de toda fixação em objetos empíricos "pode ser fetichista" e que um horizonte de reconhecimento intersubjetivo da autonomia e da dignidade dos sujeitos "pode comportar a submissão e a humilhação" sem que isto implique em contradição performativa.

Aqui, o contra-senso parece absoluto, já que não é evidente que o masoquista regule sua conduta a partir de uma vontade liberada de objetos patológicos e a partir de um horizonte de reconhecimento intersubjetivo. É neste ponto que devemos analisar dois procedimentos centrais em todo cenário masoquista: o "contrato" e a "fetichização".

De um lado, o contrato é necessariamente reconhecimento do desejo entre iguais que se reconhecem mutuamente como sujeitos. Reflexividade intersubjetiva que Deleuze identificou claramente ao afirmar que, no cenário masoquista:

Nós estamos diante de uma vítima que procura um carrasco e que necessita formá-lo, persuadi-lo e fazer uma aliança com ele para a empresa a mais estranha [...] é o masoquista que a forma [a dominadora] e a traveste, e lhe sussurra as palavras duras que ela lhe endereça (DELEUZE, 1967, p. 22).

Essa figura da vítima que forma um carrasco nos lembra que se transformar em puro objeto do gozo do outro "por contrato", ser Senhor e escravo "por contrato" é uma forma absolutamente paródica de reconhecer a autonomia dos sujeitos. Pois "a figura do contrato pressupõe previamente o reconhecimento da dignidade dos sujeitos que deixam de lado sua dignidade" a fim de sustentar uma encenação limitada no tempo e no espaço. Podemos dizer que a realização suprema do ideal de autonomia presente na Lei moral consistiria em poder "gozar de maneira paródica" do papel da heteronomia e da submissão. ${ }^{3}$

O contrato masoquista aparece então como ato supremo de humor. Por meio desse humor, o cenário de submissão masoquista aparece como "construção de um espaço de simulacros", jogo de simulação que é absolutamente consistente com os imperativos de dignidade e de autonomia própria à Lei moral. Não se trata de uma simples encenação, mas de um simulacro no sentido de ser um caso que, ao mesmo tempo, realiza e nega a Lei em suas expectativas iniciais de performance. Assim, o masoquismo mostra como "o reconhecimento da transcendentalidade da Lei pode permitir o advento de um espaço de simulacros". Esse é o ponto fundamental posto pelo masoquismo ao insistir que a significação da autonomia pode comportar a simulação da servidão: é possível inverter as "designações" da Lei sem, com isso, entrarmos em contradição a respeito de sua "significação". Por isso, podemos dizer: há um modo de realização do reconhecimento da Lei por meio da articulação de simulacros. 
Essa questão do contrato masoquista nos leva a um ponto central da estratégia deleuzeana. Lembremos do motivo freudiano da subordinação da "autonomia" da Lei moral à experiência de culpabilidade vinda da pressão sádica do supereu contra o eu. Para Freud, tudo se passa como se a "faticidade" da Lei moral fosse indissociável de uma experiência de culpabilidade objetiva que apareceria, inclusive, como saldo de processos de socialização do desejo sexual nas sociedades modernas dependentes de mecanismos de repressão.

No entanto, é possível atualmente falar em uma obsolescência da culpabilidade enquanto saldo das experiências de socialização e de internalização da Lei moral, isso em prol de uma certa "flexibilização" da Lei que pode ser compreendida a partir da lógica da paródia. Creio ser esse o contexto adequado para a compreensão da leitura deleuzeana do masoquismo. Pois devemos lembrar que, para Deleuze, o masoquismo não seria simplesmente a encenação da indissolubilidade entre a afirmação do primado da Lei e a experiência de culpabilidade e humilhação do eu. Na verdade, ele seria um surpreendente movimento de anulação da culpabilidade por meio da "parodização" da Lei. "Movimento de subversão da Lei" com sua experiência subjetiva de culpabilidade, o masoquismo conservaria os motivos da Lei apenas para destruir sua força performativa. Para tanto, Deleuze insiste que, no masoquismo, a culpabilidade vinda da pressão sádica do supereu repressivo seria encenada de maneira paródica mediante a externalização do supereu na figura da dominadora. Nessa chave interpretativa, o que é humilhado no masoquismo pela figura feminina é aquilo que, no sujeito, moldou-se à semelhança da identificação paterna, é aquilo que no sujeito assemelha-se à imagem do pai. Ou seja, em vez da repressão do supereu paterno como resultado da internalização da identificação paterna, teríamos, no masoquismo, a sua destruição. Ao insistir na recorrência do tema "Você não é um homem, eu te transformo em um" que sai da boca das dominadoras dos romances de Sacher-Masoch, Deleuze lembra que, aqui, "ser um homem":, "não significa em absoluto fazer como o pai, nem ocupar seu lugar. É, ao contrário, suprimir seu lugar e a semelhança a ele a fim de permitir o nascimento de um homem novo" (DELEUZE, 1967, p. 86).

Esse declínio da figura paterna é um dado fundamental não tanto por privar o sujeito do modelo de papel a representar, mas por permitir que fantasias primitivas dominem o desenvolvimento subseqüente do supereu. Nesse caso, essas fantasias primitivas masoquistas (e aqui podemos seguir Deleuze) dizem respeito principalmente à mãe fálica e a um certo supereu constituído a partir de figuras femininas. Sua lógica de "paródia" da repressão apenas permite o advento de uma figura possível de um supereu "materno" não mais vinculado a mecanismos repressivos, mas ao imperativo do gozo. Dessa forma, por meio do masoquismo, Deleuze parece nos fornecer uma lógica da ação organizada a partir de uma certa possibilidade de "interversão paródica" da Lei que aparece como modo de conciliação entre exigências de satisfação irrestrita e reconhecimento da Lei. Tal lógica teria um conteúdo subversivo em situações sociais nas quais a Lei procura legitimação a partir da fundamentação de seus modos de aplicação concreta. 


\section{Fetiches, SEMBLANTES E SIMULACROS}

Há ainda um outro ponto fundamental na re-compreensão dos modos de sexuação que aparece no bojo da leitura deleuzeana do masoquismo. Trata-se da centralidade do fetichismo na organização da economia libidinal do masoquismo. É o próprio Deleuze que insiste nesse ponto ao lembrar como as operações de suspensão, de congelamento e de idealização próprias ao fetichismo são fundamentais para a composição do cenário masoquista e, em especial, para a composição daquela que encarnará a paródia da Lei: a dominadora. Esse problema do fetichismo é elemento central na nossa discussão por aparecer como a realização mais bem acabada daquilo que vimos até agora sob o nome de simulacro.

Podemos dizer que o fetiche é um exemplo privilegiado de noções, como o simulacro, porque ele não é aquilo que procura se colocar como "representação" adequada do objeto do desejo, nem aplicação o que seria um caso do genérico do desejo enquanto conceito. Essa inadequação fundamental entre um desejo que não pode ser compreendido no interior de uma moral naturalista e os objetos empírico - inadequação radical entre desejo e empiria que a psicanálise de orientação lacaniana chama de castração - é um elemento fundamental na constituição do fetiche. No entanto, por meio do fetiche, é possível produzir um objeto que, ao mesmo tempo, é uma aparência posta como aparência e que permite ao sujeito "agir como se não soubesse" estar diante de uma aparência.

Primeiramente, compreender como um objeto tal qual o fetiche é possível significa compreender o modo de negação que o suporta. Nesse sentido, faz-se necessária uma análise da negação perversa própria a Verleugnung.

A especificidade dessa forma perversa de negação vem do fato de que, contrariamente aos outros modos de negação presentes na clínica analítica e que fundamentam estruturas nosográficas como a neurose (Verneinung) e a psicose (Verwerfung), não há nenhum não-saber sobre a castração na Verleugnung. Não se trata aqui de recalcar ou de expulsar o saber sobre a castração e sobre o vazio de objeto que ela impõe. Nós estamos diante de um movimento duplo no qual saber e não-saber podem coexistir conjuntamente. Em vez do saber marcado pelo esquecimento próprio ao recalcamento, a Verleugnung é uma contradição posta que é, ao mesmo tempo, contradição resolvida. Dois julgamentos contraditórios estão presentes no eu, mas sem que o resultado de tal contradição seja um nada. Há, na verdade, produção de um objeto a partir de determinações contraditórias. Esse objeto terá a consistência de um simulacro ou, para falar como Lacan, de um semblante.

Sobre a noção lacaniana de semblante, lembremos como, desde o início de suas considerações sobre o papel do Imaginário na organização do diverso da experiência sensível, Lacan nunca cessou de denunciar o caráter "enganador" da aparência. Ele se pergunta: "Por que o desejo é, na maior parte do tempo, outra coisa do que parece ser?" (LACAN, 1978, p. 258). Assim, quando Lacan fala da aparência como engano e do final de análise como um "declínio imaginário do mundo" (LACAN, 1978, p. 258) capaz de nos desvelar a estrutura significante 
que constitui o mundo dos objetos do desejo, poderíamos pensar que tal estratégia indica a existência de uma espécie de oposição entre aparência e essência (ou entre fenômeno e estrutura) em vigor no interior da psicanálise lacaniana. Tal desconfiança nos leva a colocar uma questão: o que acontece com a aparência (e com as escolhas empíricas de objeto) quando o desejo se revela na sua verdade de falta-a-ser desprovido de objeto, desejo que alcança sua verdade na determinação transcendental do falo?

A resposta de Lacan consiste em dizer que a aparência se transforma em semblante, ou seja, "aparência que se coloca enquanto pura aparência". Nesse sentido, a característica maior do semblante é que ele: "não é semblante de outra coisa", ou seja, ela não nos reenvia à referência alguma para além da superfície das aparências. Contrariamente à imagem narcísica, imagem que era aparência enganadora resultante de uma "reificação" e de uma "naturalização" do olhar constitutivo do Outro, o semblante não é imagem reificada. Diante do semblante, o sujeito sabe que está diante de uma pura aparência que não se coloca mais como representação que ainda obedeceria ao princípio de adequação. Tais considerações sobre o semblante serão importantes para definirmos o estatuto do fetiche.

A fim de melhor compreender esse ponto, devemos primeiramente retornar a Freud. A trajetória da Verleugnung no texto freudiano é complexa, pois o termo é utilizado tanto para descrever a negação psicótica da realidade quanto para a negação perversa da castração da mulher. Por exemplo, em A perda da realidade na neurose e na psicose, de 1924, Freud dirá que a neurose não desmente a realidade, ela só quer nada saber; a psicose a desmente e procura substituí-la. Mas Freud é o primeiro a "arrepender-se de ter ousado ir tão longe". Há casos nos quais uma "representação" da realidade é desmentida e, no entanto, não temos psicose. O que pode nos explicar por que encontramos nos textos ulteriores de Freud a tendência em restringir o uso da Verleugnung a uma operação específica: a relação à castração da mulher.

Se retornarmos ao fetichismo, poderemos compreender melhor a estrutura da Verleugnung. Freud estrutura sua teoria do fetichismo a partir da temática da defesa contra a percepção da castração feminina e do reconhecimento da diferença sexual que tal percepção implica. De fato, "percepção" é um termo que sempre suscitou problemas no interior dessa teoria do fetichismo já que, de uma certa forma, a castração feminina, como ausência do pênis, é um fantasma, e não uma realidade que poderia ser percebida. Podemos conservar essa temática da castração apenas se admitirmos o "valor simbólico da castração" enquanto nome do reconhecimento da inadequação entre o desejo e os objetos empíricos.

Mas sigamos inicialmente o esquema freudiano. Sabemos que, para Freud, não se trata simplesmente de expulsar ou de recalcar a castração. Notemos que o fetichista tem um "saber sobre a castração". Ele "sabe atualmente" que a mulher é castrada. Nesse sentido, contrariamente à psicose, há uma primeira simbolização (Bejahung) da castração. Como dirá Freud: 
Não é exato dizer que a criança, após sua observação da mulher, tenha salvo sem modificações sua crença (Glauben) no falo da mulher. Ele a conservou, mas igualmente a abandonou; no conflito entre o peso da percepção não desejada e a força do desejo oposto (Gegenwunsches), ele encontrou um compromisso. (FREUD, 1999, p. 313)

O mesmo objeto pode então negar a experiência da diferença sexual e da castração, funcionando como um substituto do pênis ausente da mulher, e afirmar o que ele nega. Freud é claro a respeito da idéia de que o fetiche seria uma contradição encarnada, já que ele: "concilia duas afirmações incompatíveis: a mulher conservou seu pênis e o pai castrou a mulher". Toda a complexidade do fetiche vem do fato de ele ser suporte de uma construção fantasmática (a mulher fálica) ao mesmo tempo em que reconhece o real da castração. ${ }^{4}$

Mas qual é o processo que permite ao fetichista conciliar duas afirmações aparentemente tão incompatíveis? Em 1938, Freud falará de um deslocamento de valor (Wertverschiebung) que transfere a significação do pênis (Penisbedeutung) a uma outra parte do corpo (ou a um outro objeto: látex, peles etc.). Mas devemos notar que tal deslocamento é inscrito como marca suportada pelo objeto. Para compreender a Verleugnung faz-se necessário lembrar que o objeto substituto (Ersatz) é posto como "sendo apenas um substituto". Em todo fetiche há a insistência no caráter factício do objeto (que não é estranho à origem portuguesa da palavra: "feitiço, factício, fetiche").

Graças a isso, a Verleugnung pode aparecer como uma surpreendente "negação da negação". O sujeito nega a castração por meio do deslocamento de valor e da produção de um objeto fetiche mas, ao mesmo tempo, ele nega essa negação ao apresentar o fetiche como "um simples substituto" ou ainda, se quisermos, como um semblante. Nesse sentido, podemos dizer que o fetichista já faz a crítica do fetichismo tal como um intelectual aufklärer. Lacan nos fornece uma fórmula feliz dessa lógica da Verleugnung ao dizer que, com o fetichista: "Parece-me estarmos diante de um sujeito que nos mostra, com uma rapidez excessiva, sua própria imagem em dois espelhos diferentes” (LACAN, 1994, p. 86).

Há uma "clivagem" do eu que lhe permite, ao mesmo tempo, identificar-se com a mulher castrada (ao reconhecer a castração) e com o falo imaginário que lhe faltaria. É a estrutura de semblante própria ao fetiche que permite ao sujeito sustentar tal clivagem sem necessitar de operações de recalcamento. Nesse sentido, digamos com Rabant (1990, p. 132): “O 'desmentidor' é enganado pela metade através de seu próprio desmentido". Na dimensão do fetichismo, o sujeito sabe que portar uma bota de látex negro não permite à mulher ser menos castrada do que antes. Há pois um "saber da verdade", mas isso não o impede de gozar como se ele não soubesse. Como dizia Octave Manonni (1969, p. 71), em um texto célebre sobre a estrutura da crença fetichista, a proposição por excelência de um pensamento fetichista obedece sempre à forma: "eu sei bem, mas mesmo assim...". Eu sei bem que a mulher é castrada, mas posso gozar da aparência de sua não-castração, tal como em um cenário masoquista construído por meio de um 
contrato de simulações. Proposição que, não por acaso, nos remete novamente à formula do cinismo fornecida por Sloterdjik (1983): "Eles sabem o que fazem, e continuam a fazê-lo". Assim, se, no interior da discussão sobre o fetichismo, Manonni percebe que "tudo se passa como se vivêssemos em um meio no qual flutuam crenças que aparentemente ninguém assume" (MANONNI, 1969, p. 19) é porque o fetichismo nos lembra que a crença não é um problema de estados intencionais, mas de estrutura da práxis. Talvez o fetichismo seja um bom exemplo para nos mostrar como acreditar não é exatamente uma questão de ter certos estados intencionais, mas de agir de certas maneiras.

Esse é o ponto importante para nós. O fetiche implica um modo peculiar de subjetivação da falta de objeto adequado ao desejo pressuposta pela castração. Se nos voltarmos ao masoquismo, veremos a idealização fetichista inicialmente como anulação de toda determinação qualitativa e da integralidade dos atributos imaginários de "uma" mulher. Ela se transforma em objeto que passou por uma desafecção, puro suporte de um traço (um sapato, um certo brilho no nariz etc.) que determina seu valor no interior da economia fantasmática de gozo. Nesse sentido, podemos dizer que o fetiche é: "presença real do objeto como ausente" (REY-FLAUD, 1994, p. 100), já que ele permite o advento de uma feminilidade que se apresenta por meio do vazio da anulação de "uma" mulher.

O humor masoquista consiste aqui em transformar a fixação "patológica" fetichista no reconhecimento da inadequação fundamental entre o vazio do desejo e os objetos empíricos. Ele admite a existência de uma inadequação entre desejo e os objetos empíricos, mas ele age como se não soubesse. Lacan se serve, por exemplo, da metáfora instrutiva do fetiche como um véu no qual "o que está para além como falta tende a realizar-se como imagem" (LACAN, 1994, p. 155). Mas essa realização da falta como imagem é feita por meio de uma estranha transformação do fetiche em "ídolo da ausência" (LACAN, 1994, p. 155) - o termo "ídolo" serve aqui para sublinhar a potência da fascinação enquanto desejo de desmentido. Como se o reconhecimento da inadequação dos objetos empíricos à vontade pura pudesse realizar-se como vínculo a objetos "que se colocam deliberadamente como inadequados". Ou seja, "como se a rejeição radical da serialidade dos objetos empíricos nos levasse não apenas à destruição sádica do sensível, mas à anulação fetichista da empiria através da sua conformação à imagem do simulacro". O que nos permite perguntar se o nome correto desta "arte de superfície" que Deleuze procura trazer por meio, entre outros, do humor masoquista não seria simplesmente "fetichismo".

Por outro lado, esse modo perverso de operar a subjetivação da falta mostra como o fetiche opera de maneira idêntica ao conceito lacaniano de falo. Podemos mesmo dizer que ele se coloca como realização cínica e paródica da exigência de sexuação e de subjetivação do desejo mediante a identificação simbólica ao falo. Assim, ao contrário do que poderia inicialmente parecer, essa discussão sobre o fetichismo não está restrita simplesmente a quadros clínicos específicos da perversão. Conforme estudos psicanalíticos recentes insistem, o próprio Freud, em textos finais, caminhava na tentativa de repensar a centralidade dos mecanismos 
de repressão em prol de uma teoria baseada na Verleugnung e na clivagem do eu (BASS, 2000).

\section{JUdiTH BUTLER E OS LIMITES DA POLÍTICA DA PARÓDIA}

Algo desse movimento deleuzeano de torção da Lei presente no masoquismo e no fetichismo funciona como base de certas considerações de Judith Butler sobre sexo e política. Reconhecida como uma das teóricas mais importantes dos estudos de gênero, Butler tem o interesse de tentar ver as práticas de gênero como espaço privilegiado para a reflexão sobre o político e sobre a revitalização de suas categorias. Novamente, veremos a aceitação da noção contemporânea de sexo como lugar de enunciação da verdade e a léxis que suporta tal enunciação deve passar pela paródia e pela afirmação de algo muito próximo ao que Deleuze compreende por simulacro e Lacan compreende por semblante (embora Butler não esteja disposta a aceitar tais proximidades, em especial, a segunda).

Podemos dizer que a base da perspectiva de Judith Butler encontra-se na tentativa de fornecer uma teoria anti-representativa do sexual. Identidades sexuais não devem ser pensadas como "representações" suportadas pela estrutura binária de sexos. Trata-se, ao contrário, de tentar escapar da própria noção de representação por meio de uma "teoria performativa do sexual". Teoria que sustenta a possibilidade de realização de atos subjetivos capazes de produzir de maneira plástica novas identidades sexuais ou, ainda, novos modos de gozo que subvertam as interdições postas pelo sistema binário de gêneros.

Tal teoria nasce de uma tomada de posição que procura levar às últimas conseqüências a distinção entre "sexo" (configuração determinada biologicamente) e "gênero" (construção culturalmente determinada). No seu caso, não se trata de fornecer uma nova versão da distinção clássica entre natureza e cultura, até porque gênero, segundo Butler, "é o aparato discursivo/cultural através do qual 'natureza sexual' ou 'sexo natural' são produzidos e estabelecidos como 'prédiscursivos', como prévios à cultura, uma superfície politicamente neutra 'na qual' a cultura age" (BUTLER, 1999, p. 11). Essa noção de gênero como ante-câmara de produção da "natureza sexual" permite a Butler primeiramente defender o caráter ideológico de uma noção binária de gênero (masculino/feminino), já que: "A pressuposição de um sistema binário de gênero depende da crença em uma relação mimética entre gênero e sexo na qual gênero espelha sexo ou é, por outro lado, restringido por ele" (BUTLER, 1999, p. 10). Posteriormente, ela insistirá que a tarefa política central consistiria na crítica das categorias identitárias engendradas e naturalizadas pelo ordenamento jurídico - donde se deduz a função política de uma teoria performativa do sexual. Ou seja, não mais as estratégias de reconciliação com o universal da Lei, mas, novamente, a realização de aspirações do político como "desarticulação" da Lei.

O que nos interessa aqui é a anatomia dessa crítica. Pois ela não deve levar à naturalização de outras categorias identitárias, mas à posição de identidades sexuais que sejam a própria encarnação da desestruturação da noção de representação, identidades que seriam a apresentação da desestabilização das identida- 
des. Daí por que essa crítica das categorias identitárias seria performativamente implantada por meio, por exemplo, de práticas paródicas de gênero, como aquelas levadas a cabo por drag-queens. Pois ao operar uma "dupla inversão" que consistiria em embaralhar as distinções essência/aparência para afirmar, ao mesmo tempo: "minha aparência exterior é feminina, mas minha essência interior (o corpo) é masculina" e "minha aparência exterior é masculina (meu corpo), mas minha essência interior é feminina", as drags fariam uma espécie de "crítica à reificação dos gêneros". Butler poderá afirmar assim que elas revelariam: "estes aspectos da experiência de gênero que são falsamente naturalizados como uma unidade através da ficção regulatória da coerência heterossexual" (BUTLER, 1999, p. 175). Crítica paródica que, por inaugurar um deslocamento perpétuo de identidades, teria a força de sugerir a abertura a processos de ressignificação capazes de se disseminarem na malha social. Butler pode ainda usar outros exemplos, como as queers (mulheres masculinizadas que escolhem homens homossexuais, realizando com isso escolhas heterossexuais de objeto que não se organizam mais como escolhas heterossexuais) e práticas como strapon (casais heterossexuais que invertem seus papéis sexuais).

Essa crítica articulada por meio do embaralhamento da diferença ontológica entre essência e aparência só é possível porque a aparência é elevada aqui à condição de simulacro, ou ainda, de fetiche que desorienta a própria noção de identidade e representação fixa por, ao mesmo tempo, adequar-se e não se adequar à diferença sexual e aos modos de sexuação tais como seriam postos pela Lei. Assim, tudo se passa aqui como se: "ao agir (performing) e ao chamar a atenção para a estrutura do gênero como performance, nós pudéssemos ser liberados de uma política dogmática ou de uma política que aspira saber o real de maneira segura. Não podemos escapar do sistema de identidade ou da ilusão de que há um sujeito que fala. Mas podemos agir, repetir ou parodiar todos estes gestos que criam um sujeito" (COLEBROOK, 2004, p. 125).

De qualquer forma, Butler constrói, tal como Deleuze, um horizonte de socialização organizado por meio da submissão paródica à Lei mediante a torção de suas consequiências performativas. De fato, trata-se, para Butler, de levar os sujeitos a assumir a plasticidade infinita dos modos de gozo por meio da pluralidade de regimes de "estilização do corpo". Assunção que se dá graças a um modo de submissão à Lei que implica a desarticulação dos seus processos de ordenamento. Deleuze procurava algo semelhante mediante o masoquismo e sua lógica fetichista de constituição do objeto. Por outro lado, não deixa de ser extremamente significativo que duas perspectivas teóricas que procuram pensar a maneira com que a verdade acede ao campo do sexual e fazer a crítica a uma certa noção de reconciliação herdada da modernidade acabem convergindo na tematização de uma certa razão cínica em operação em modos de sexuação que procuram colocar-se como horizontes para uma contemporaneidade não mais dependente da repressão àquilo que é da ordem do sexual.

Mas há um ponto que merece um destaque especial aqui. É fundamental notar que tais perspectivas só podem se colocar como dotadas de forte potencial 
político por pressuporem uma Lei simbólica que organiza os modos de socialização e de subjetivação do campo do sexual e que funcionaria (ou, ao menos, tentaria funcionar) como Lei que procura naturalizar seus modos de aplicação reificando aquilo que ela enuncia e que teria, como correlata, a posição de falsas consciências marcadas pelo desconhecimento ideológico. "Como se estivéssemos ainda às voltas como figuras da ideologia dependentes das temáticas da reificação, da falsa consciência e da alienação na dimensão da aparência".

No entanto, nada disso é certo atualmente. É bem provável que a contemporaneidade esteja diante de uma situação histórica na qual a Lei e suas figuras ideais de socialização tendem a funcionar de maneira paródica e autoderrisória. Figuras de um poder capaz de "revelar o segredo de seu funcionamento e continuar a funcionar como tal" (ZIZEK, 2003, p. 100). Esse fato está vinculado a uma modificação maior nos modos de operação da ideologia já diagnosticados desde Adorno: a ironização absoluta dos modos de vida e condutas. ${ }^{5}$ Ironização que nos coloca diante daquilo que Peter Sloterdijk (1983) um dia chamou de "ideologia reflexiva", posição ideológica que porta em si mesma a negação dos conteúdos que ela apresenta. Maneira astuta de perpetuá-los mesmo em situações históricas nas quais eles não podem mais esperar enraizamento substancial algum.

Se esse for realmente o caso, o que dizer então de práticas políticas que procuram tirar sua força subversiva da paródia em contextos socioculturais nos quais o poder já ri das suas próprias injunções e já marca os processos de socialização com o selo da ironização? Não seria sintomático que todas as práticas subversivas tematizadas por Deleuze (masoquismo, fetichismo) e por Butler (processos de desorientação da diferença binária de sexos) apareçam atualmente como motivos maiores das representações disponibilizadas pelo universo mercantil do consumo?

\section{Notas}

1 Isto talvez nos explique por que Lacan será obrigado a relativizar a centralidade do falo nos processos de socialização do desejo e de estruturação dos campos de sexuação. Sobre esse ponto, remeto ao meu Safatle (2006).

2 É claro, Deleuze, ao falar de Sade, tem em mente também Lacan e sua estratégia de pensar o falo como significante puro, pura forma do desejo. Uma leitura atenta de Kant com Sade, de Lacan, pode mostrar como o próprio Lacan reconhece tal aproximação no interior de um movimento de autocrítica. Ver Safatle (2003).

3 De onde se segue, por exemplo, a afirmação de Lacan, que em larga medida concorda com Deleuze a respeito do problema do masoquismo: "enquanto [Sacher-Masoch] desempenha o papel do servo que corre através de sua dama, ele tem todas as dificuldades do mundo em não explodir de rir, ainda que ele tenha o ar mais triste possível, Ele só retém o riso com muita dificuldade" (LACAN, 1966-1967, sessão de 14/6/67).

4 Alguns psicanalistas, como Alan Bass (2000), insistem, de maneira apropriada, que a oscilação entre o reconhecimento da castração feminina e da não-castração é, na verdade, uma oscilação entre dois fantasmas, já que a negação fetichista incide, na verdade, sobre o reconhecimento da diferença sexual. O fetichista negaria a diferença sexual por meio da fantasia de um monismo fálico e da crença de que só há gozo fálico. Como se o gozo feminino só pudesse ser aceito mediante a transformação da mulher em suporte de atributos fálicos (o que não deixa de ser uma conseqüência precisa da noção lacaniana de "mascarada"). O que dá ao fetichismo um "momento de verdade". Ele nos lembra o impasse de pensarmos a subjetivação do desejo por meio do Falo como significante central dos processos de sexuação tanto para a posição masculina quanto para a posição feminina. 
5 Tomo a liberdade de remeter aqui ao meu Safatle (2005).

\section{REFERÊNCIAS}

BASS, A. Difference and disavowal: the trauma of Eros. [S.1.]: Stanford University Press, 2000.

BUTLER, J. Gender trouble. New York: Routledge, 1999.

COLEBROOK, C. Irony. New York: Routledge, 2004.

DELEUZE, G. Logique du sens. Paris: Minuit, 1969.

. Présentation de Sacher-Masoch. Paris: Minuit, 1967.

FOUCAULT, M. História da sexualidade. Rio de Janeiro: Graal, 1986.

FREUD, S. Fetichismus. In: . Gesammelte Werke. Frankfurt: Fischer, 1999. vol. XIV.

KIERKEGAARD, S. O conceito de ironia constantemente referido a Sócrates. Petrópolis: Vozes, 1991.

LACAN, J. Ecrits. Paris: Seuil, 1966.

. Séminaire I. Paris: Seuil, 1975.

. Séminaire II. Paris: Seuil, 1978.

. Séminaire III. Paris: Seuil, 1981.

. Séminaire IV. Paris: Seuil, 1994.

. Séminaire V. Paris: Seuil, 1998.

. Séminaire VII. Paris: Seuil, 1986.

. Séminaire XIV. [S.1.: s.n.], 1966-1967. Mimeografado.

MANONNI, O. Clefs pour l'imaginaire. Paris: Seuil, 1969.

RABANT, C. Inventer le réel: le déni entre perversion et psychose. Paris: Denöel, 1990.

REY-FLAUD, H. Comme Freud inventa le fétichisme et re-inventa la psychanalyse. Paris: Payot, 1994.

SAFATLE, V. A paixão do negativo: Lacan e a dialética. São Paulo: UNESP, 2006.

. O ato para além da Lei: Kant com Sade como ponto de viragem do pensamento lacaniano. São Paulo: UNESP, 2003.

. Sobre um riso que não reconcilia : ironia e certos modos de funcionamento da ideologia. Margem Esquerda, [S.1.], n. 5, 2005. 
SLOTERDIJK, P. critique de la raison cynique. Paris: Christian Bourgeois, 1983. ZIZEK, S. Fétichisme et subjectivation interpassive. Actuel Marx, [S.1.], n. 34, 2003.

Recebido em: abril/2005

Aceito em: março/2006 